\title{
Stratigraphic and palaeoecological evidence for late medieval to early modern peat extraction from bogs in Het Gooi (Western Netherlands)
}

\section{Jan Sevink* \& Bas van Geel}

Institute for Biodiversity and Ecosystem Dynamics, University of Amsterdam, Science Park 904, 1098 XH Amsterdam, The Netherlands

* Corresponding author. Email: j.sevink@uva.nl

Manuscript received: 2 November 2016, accepted: 15 May 2017

\section{Abstract}

In the Monnikenberg estate, built in the mid-19th century in a Pleistocene coversand area to the south of Hilversum (the Netherlands), a depression with a small man-made mire was found to contain the remains of a complex peaty fill of a larger mire. Microfossil study and radiocarbon dating showed that its development started at the beginning of the third millennium BC through water stagnation on a podzol in combination with a high groundwater level, and about two millennia ago the vegetation had progressed from a mesotrophic mire to an ombrotrophic bog. Such origin, development and age are in conformity with the results for some other recently studied mires in the Het Gooi region (Gijzenveen; Van Geel et al., 2016). In the Monnikenberg mire, a discrepancy was found between the radiocarbon age of the upper part of the peaty fill and its clearly medieval or younger age as evidenced by its microfossil content, notably the occurrence of pollen of buckwheat (Fagopyrum) and cornflower (Centaurea cyanus). These species were first introduced in the Netherlands during the late Middle Ages. From further observations in a large pit in the former border zone of the mire, it is concluded that this discrepancy and the unique sedimentary structures, observed in this pit, result from peat exploitation and contemporary reworking of its sandy overburden during the Late Middle Ages or Early Modern Times. This is the first evidence for local early peat exploitation for such mires in Het Gooi. The results underpin the importance of microfossil analyses for proper interpretation of radiocarbon data, when studying mire fills. Additionally, they provide further proof for the development of podzols and ericaceous vegetation prior to and independent of early prehistoric agriculture in the Dutch Pleistocene coversand areas, and for the early (pre-medieval) start of wind erosion and deposition of drift sands.

Keywords: Late Middle Ages, mire, pollen, peat extraction, vegetation succession

\section{Introduction}

Recent surveys by Sevink \& Den Haan (2012) and Den Haan \& Sevink (2014) of the Monnikenberg estate (Figs 1, 2), to the SW of the Groot Wasmeer, east of Hilversum (the Netherlands), showed that its small pool (the Monnikenven) is man-made. It is situated in a former mire, with a predominantly peaty fill developed on a stagnative podzol. This fill had been drastically affected by the building of the estate around 1840, which included the creation of the current Monnikenven, but in places the original fill seemed to be well conserved, notably in the southern border zone where more recent drift sands acted as protective cover (Fig. 3).
In some corings, this fill was over $1 \mathrm{~m}$ thick and included welldeveloped peat layers, potentially allowing for more detailed insight into the genesis and history of the area. In the border zone, the organic fill was overlain by yellowish drift sand. A core in that zone was studied for its pollen and other microfossils contents (for location and diagram 'Monnikenven-1', see Fig. 2; Fig. 5, further below). Based on radiocarbon dating of selected above-ground plant remains, the lower part of the fill at this site dated from around $1900 \mathrm{cal} B C$, while higher up ages of $\mathrm{AD}$ 0-400 cal were obtained (Table 1). As well as the reversal in time of the two upper radiocarbon dates, there was another chronological problem: the peat in the upper $50 \mathrm{~cm}$ of the studied core appeared to contain pollen of cornflower (Centaurea cyanus) and 


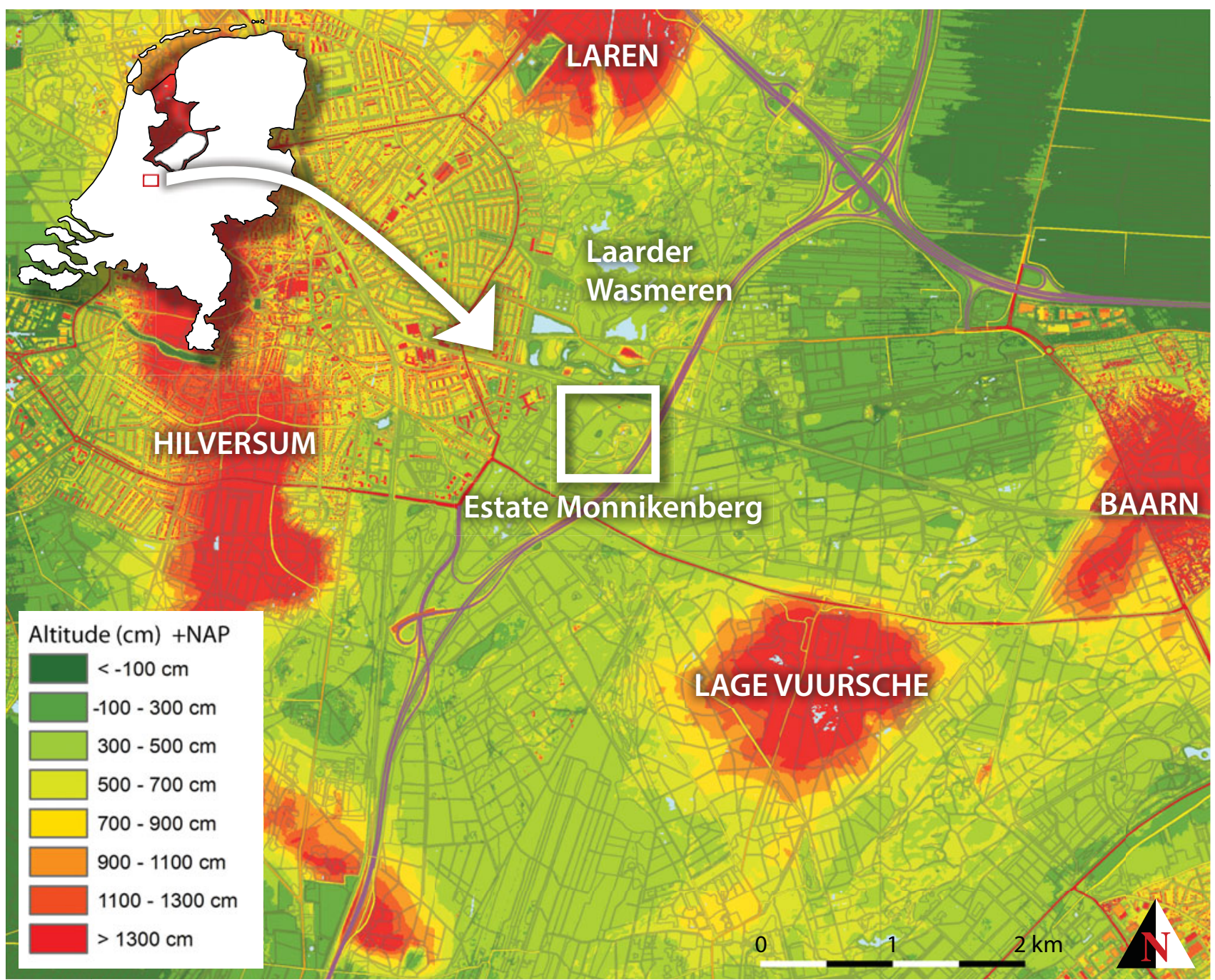

Fig. 1. The location of the Monnikenberg estate.

buckwheat (Fagopyrum). Cornflower is a plant species that first occurred in the Netherlands during the High Middle Ages (Pals \& Van Geel, 1976; Bakels, 2012); buckwheat pollen grains have been continuously present only since the Late Middle Ages (De Klerk et al., 2015). Evidently, the presence of pollen from these two species is inconsistent with the radiocarbon ages. A tentative explanation might be that people exploited peat for fuel in the Late Middle Ages or Early Modern Times, thereby disturbing the fill, but historical records of such activities do not exist.

To allow for more detailed observations and sampling of the fill, a large pit was dug in the southern border zone where the drift-sand cover was known to be up to $1 \mathrm{~m}$ thick. In this pit (Monnikenven-2; Fig. 2), very unusual chaotically stratified sedimentary structures were observed between the underlying stagnative podzol and the overlying more yellowish drift sand. These structures would not have been properly understood in cores, and resembled phenomena that in places had been observed in sections in the Groot Wasmeer border zone (Fig. 4). In the present paper, we describe these sedimentary structures
(Fig. 4). Furthermore, we present radiocarbon datings and microfossil analyses, which served to reconstruct the age and origin of the various sediments and structures. Lastly, we briefly discuss the implications of our results for the ongoing discussion on the origin and age of the Dutch heathlands and drift sands.

\section{Setting}

Today, the Monnikenven is a small shallow pool in a former mire. The current water level of the pool is at maximum around $320 \mathrm{~cm}$ + NAP (Dutch Ordnance Datum), but commonly between 270 and $290 \mathrm{~cm}+\mathrm{NAP}$, while the top of the stagnative layer is mostly between 200 and $250 \mathrm{~cm}+\mathrm{NAP}$, with some deeper parts (to about $170 \mathrm{~cm}+\mathrm{NAP})$. The latter depth is more or less equal to the current mean highest groundwater level (GHG), which lies at about $180 \mathrm{~cm}+$ NAP. This is considerably lower than the maximum groundwater level that existed in the nearby Laarder Wasmeren area around 3000 BC $(230 \mathrm{~cm}$ + NAP: Sevink et al., 


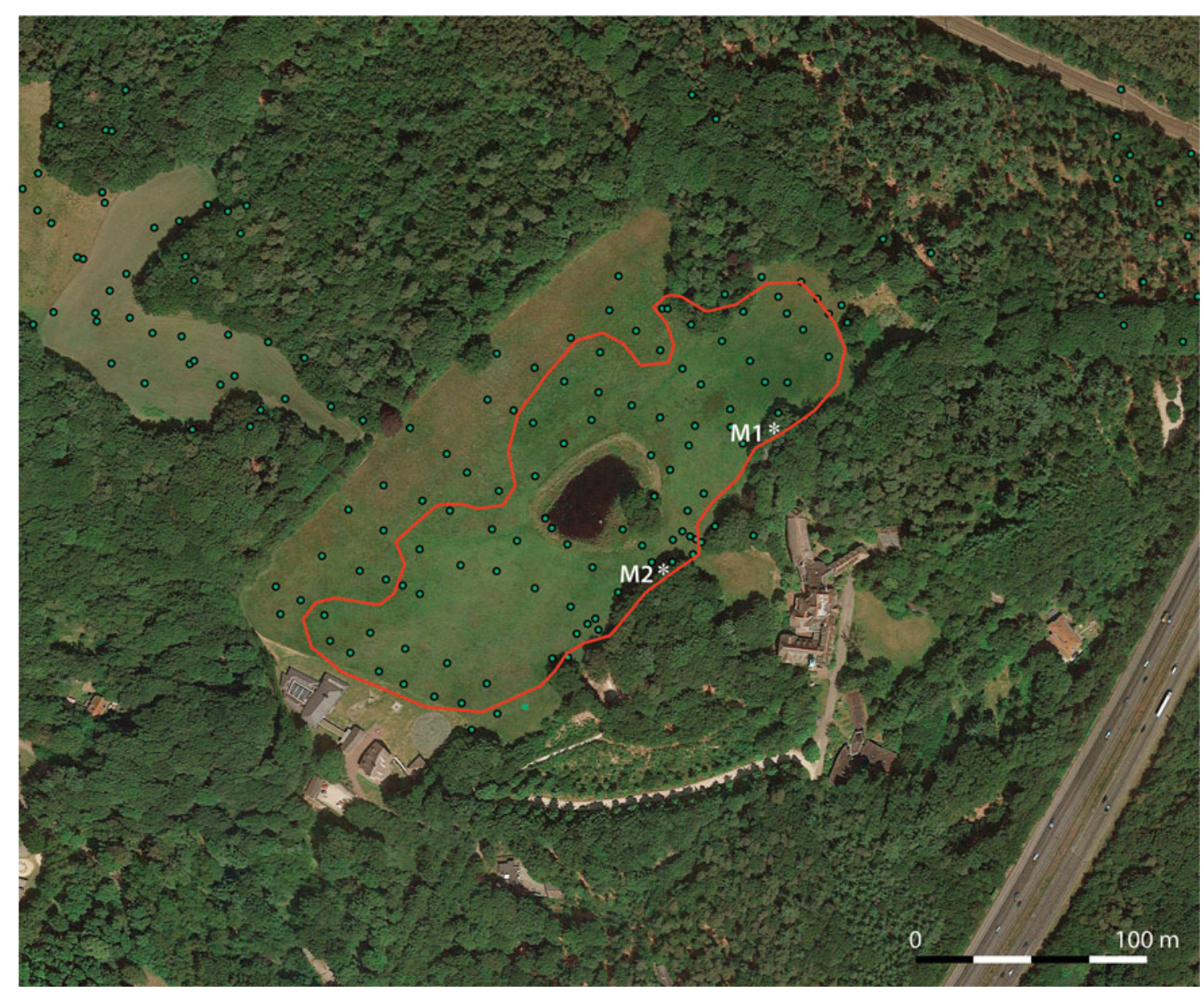

Fig. 2. The current Monnikenberg mire with the coring locations and extension of the stagnative layer (in red). Locations of Monnikenven-1 (M1) and Monnikenven-2 (M2) indicated with *

2013), and thus deeper parts of the mire were likely submerged at that time.

The current topography of the parcel in which the Monnikenven is located dates back to the mid-19th century. At that time, its higher sandy parts were levelled and the excavated podzolic material was used to fill in the lower parts, resulting in a more or less level field with a small pool (the current Monnikenven) and, adjacent to that, a low artificial hill. In its southern border zone, forest was planted with beech (Fagus sylvatica) as the major tree species (Den Haan \& Sevink, 2014).

To the NW of the Monnikenven, a similar large lake occurs (the Groot Wasmeer) that holds a complex of white sands with some thin intercalated peaty layers (Sevink et al., 2013). This lake also formed by water stagnation on a dense podzol. The sands in its border zone are of aeolian origin, but were deposited in a marshy environment, acquiring their bleached colour by post-depositional reduction, like the bleached sands in the Monnikenven mire. Aeolian deposition in this border zone was found to have started around $400 \mathrm{BC}$ (optically stimulated luminescence (OSL) dating), an intercalated peat layer dated to around 2000 years ago $\left({ }^{14} \mathrm{C}\right.$ dating), and the transition from bleached white sands to overlying yellow, terrestrial drift sands was dated at around AD 1400 by OSL (Sevink et al., 2013). The sequence resembles that observed in corings in the nearby Monnikenven.

Early maps suggest that the Groot Wasmeer lake was at least partly filled with more or less organic sediment. However, during a sanitation operation at the beginning of the 21st century, when the lake was completely drained (Sevink et al., 2008, 2012), in its central part such sedimentary fill appeared to be virtually non-existent. This eventually might be attributed to earlier extraction of peat, since such extraction is known from early historical records for Het Gooi (Borger, 1992), but there is no historical evidence for such practice in this part of the region. The absence of a fill may also be due to later human activities, including the massive dredging of sand from a deep pit in the centre of the lake in the 20th century. Whatever the causes were, they prevented a detailed study of the earlier history and formation of this lake, and its surroundings, and prompted us to study the Monnikenven fill in more detail.

\section{Materials and methods}

The southern maximum extension of the mire is indicated in Figure 2. Here the predominantly organic fill is covered by drift 

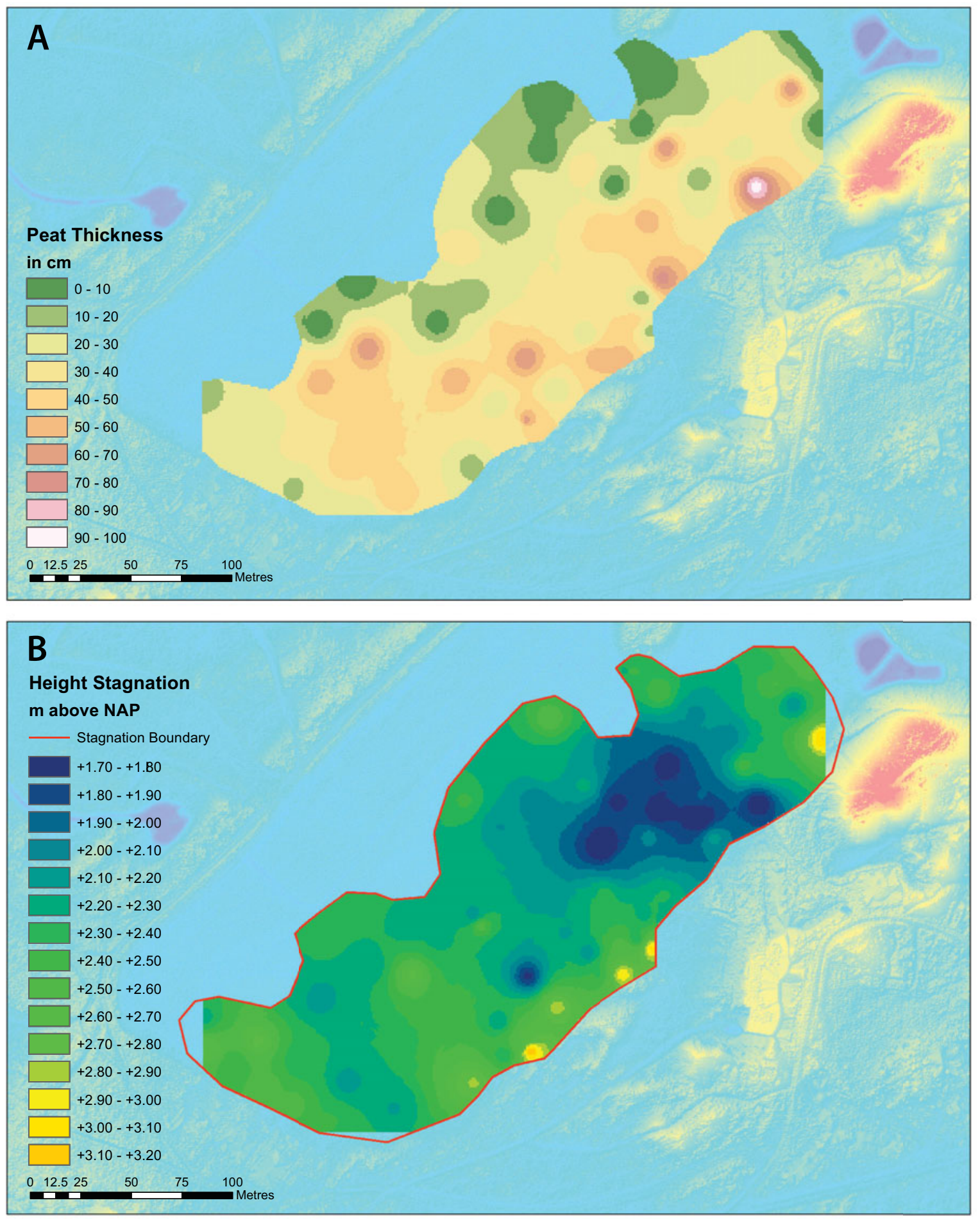

Fig. 3. (A) Thickness of the peat fill within the area with stagnative layer. (B) Altitude of the top of the stagnative layer $(m+N A P)$.

sand, the thickness of which increases to the south. Locations of the core (Monnikenven-1) and of the pit (Monnikenven-2) are indicated in Figure 2, and their lithological descriptions are presented in Table 2. The pit measured $1.5 \mathrm{~m} \times 3 \mathrm{~m}$ and had a maximum depth of about $120 \mathrm{~cm}$, groundwater being present at that depth (about $280 \mathrm{~cm}+\mathrm{NAP}, 25$ July, 2015). Plastic peel monoliths of its faces were made for detailed sedimentary facies study (see Fig. 4).

Samples were collected for microfossil analysis from the core (Monnikenven-1) and from a large monolith taken from the face of the pit (Monnikenven-2). For the analysis, subsamples of $c .1 \mathrm{~cm}^{3}$ were treated with $\mathrm{KOH}$ and subsequently 
Table 1. Radiocarbon dates of selected above-ground plant remains.

\begin{tabular}{|c|c|c|c|c|}
\hline Sample & Depth $(\mathrm{cm})$ & Lab code & ${ }^{14} \mathrm{C} \mathrm{BP}$ & Age cal yr BC/AD (1 $\sigma)$ \\
\hline Monnikenven 1-1 & $120-129$ & GrA-58003 & $1905 \pm 40$ & AD 19-221 \\
\hline Monnikenven 1-3 & $153-159$ & GrA-59785 & $1665 \pm 30$ & $\mathrm{AD} 323-429$ \\
\hline Monnikenven 1-2 & $165-180$ & GrA-58004 & $3575 \pm 40$ & $2032-1869,1847-1776 \mathrm{BC}$ \\
\hline Monnikenven 2-3 & $74-82$ & GrA-64809 & $2790 \pm 30$ & $990-905 \mathrm{BC}$ \\
\hline Monnikenven 2-2 & $98-102$ & GrA-64746 & $3615 \pm 35$ & 2025-1935 BC \\
\hline Monnikenven 2-1 & $107-110$ & GrA-64745 & $4305 \pm 35$ & $3005-2990,2930-2885$ BC \\
\hline
\end{tabular}

Calibration by 0xCal v4.24 (Bronk Ramsey, 2013); IntCal13 (Reimer et al, 2013).
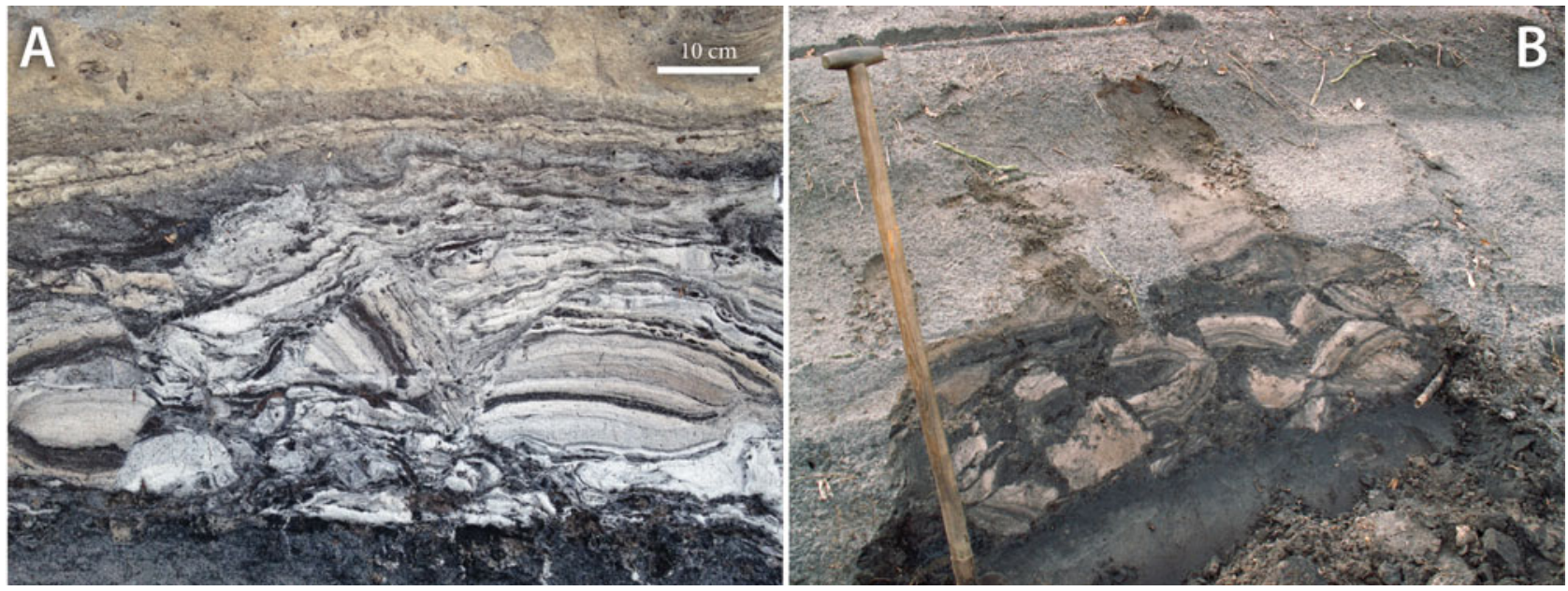

Fig. 4. (A) The rare sediment structures in the pit Monnikenberg-2. (B) Sedimentary structure from the southern border zone of the Groot Wasmeer.

acetolysed according to Fægri et al. (1989). For the separation of organic material from mineral particles, a bromoform-ethanol mixture (specific gravity 2) was used. The microfossils were embedded in glycerine jelly, and microscope slides were sealed with paraffin. Pollen was identified using Beug (2004), Moore et al. (1991) and a pollen reference collection. Non-pollen palynomorphs were identified according to Van Geel (1978) and Van Geel \& Aptroot (2006).

Samples for radiocarbon dating were taken from both the core (M1) and the pit (M2). They were treated with $\mathrm{KOH}$, after which botanical above-ground macrofossils were handpicked from the sieve fraction $>160 \mu \mathrm{m}$ (charred and non-charred plant remains of ericaceous species including twigs, seeds and flowers). The samples were washed and dried. AMS radiocarbon dating was carried out at the Centre for Isotope Research, Groningen University. Samples were pre-treated following the standard procedure (A-B-A). The dry weight of all samples was more than $10 \mathrm{mg}$ and therefore sufficient for ${ }^{14} \mathrm{C}$ AMS dating. The results were reported in conventional radiocarbon years, corrected for isotopic fractionation using the stable isotope ratio $\partial^{13} \mathrm{C}$, and the conventional half-life (Mook \& Van der Plicht, 1999).

In the text, ${ }^{14} \mathrm{C}$ dates are reported in years cal $\mathrm{BC}$ or cal $\mathrm{AD}$ (Table 1) and OSL dates as years $B C$ or $A D$, and not as years $\mathrm{BP}$, to prevent confusion resulting from the differences between reference years used for ${ }^{14} \mathrm{C}$ dating (1950) and OSL dating (year of analysis), and true calendar years.

\section{Results and discussion}

\section{Sediments and radiocarbon ages}

The Monnikenven-1 core consisted of non-stratified yellow drift sand over about $70 \mathrm{~cm}$ peat/white-sand complex resting on a humic podzol. The latter probably developed in coversand. The radiocarbon ages (Table 1) point to an onset of sedimentation on top of the podzol (at about 210-225 cm + NAP) at the beginning of the second millennium $\mathrm{BC}$ and a start of the massive drift sand deposition in a terrestrial environment around the beginning of the 1st millennium $A D$, similar to the results for the Groot Wasmeer.

In the Monnikenven-2 pit, the peat/white-sand complex appeared to be composed of chaotically stratified sediment, covering a podzol with an intact, well-conserved peaty $0 / \mathrm{H}$ horizon (see Fig. 4). Upward, this chaotic deposit grades into a thin layer of more yellowish sandy sediment with vague horizontal stratification and some fine, humic layers. This again is covered by $70-80 \mathrm{~cm}$ of a mixture of irregular yellow to slightly humic (darker) large 'soil fragments', indicating that the original soil 

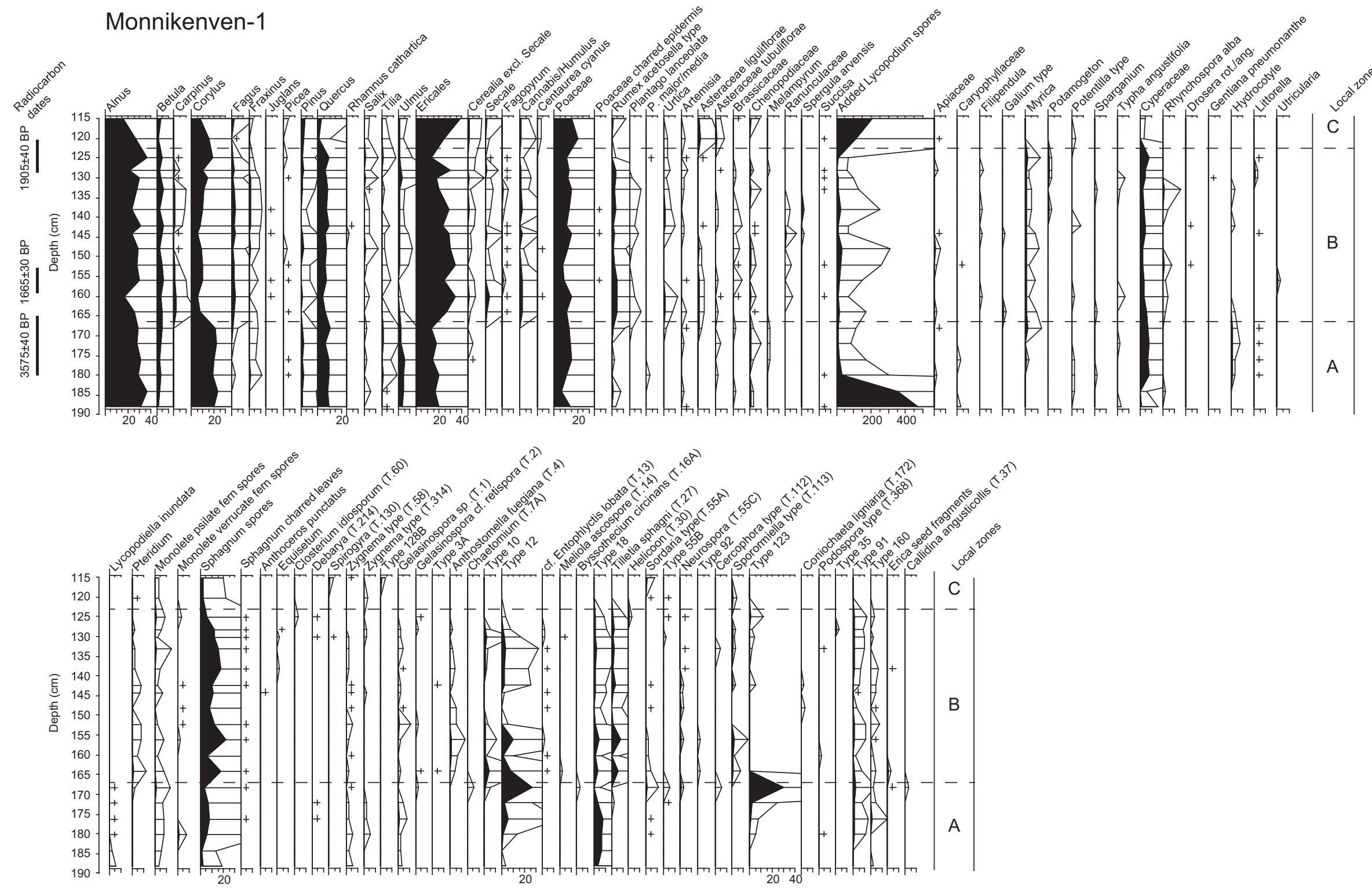

Fig. 5. Microfossil diagram of Monnikenven-1. 
Table 2. Description of sections sampled.

\begin{tabular}{|c|c|c|}
\hline Depth (cm) & Material & ${ }^{14} \mathrm{C}$ sample \\
\hline \multicolumn{3}{|c|}{ Monnikenven-1 (at $3.55 \mathrm{~m}+\mathrm{NAP}$ ) } \\
\hline $0-112$ & Yellow sand & \\
\hline $112-126$ & Humic sand & \multirow[t]{2}{*}{$120-129 \mathrm{~cm}$} \\
\hline $126-127$ & Transitional (peat to sand) & \\
\hline $127-152$ & Sandy peat & \\
\hline $152-158$ & Peat & \multirow[t]{2}{*}{$153-159 \mathrm{~cm}$} \\
\hline $158-161$ & Sandy peat & \\
\hline $161-169$ & Peat & \\
\hline $169-181$ & Peat, downward more sandy & $165-180 \mathrm{~cm}$ \\
\hline $181-186$ & Brown sandy Ah/Bh & \\
\hline \multicolumn{3}{|c|}{ Monnikenven-2 (at 3.85/3.90 m + NAP) } \\
\hline $0-74$ & Mixture of yellow and grey (humic) sand, abundant roots and some discontinuous humic layers. & \\
\hline $74-82$ & Thinly bedded alternation of humic (dark) and yellow sand & $74-82 \mathrm{~cm}$ \\
\hline $82-110$ & Irregular mosaic of blocks and layers composed of white sandy and dark, humic to peaty beds & $98-101 \mathrm{~cm}$ \\
\hline $110-120$ & 0/H-Ah Peaty topsoil of underlying podzol & $107-110 \mathrm{~cm}$ \\
\hline$>120$ & E and Bh of buried podzol & \\
\hline
\end{tabular}

The description of Monnikenven-2 refers to the section shown in Figure $4 \mathrm{~A} .{ }^{14} \mathrm{C}$ samples were taken from this section (74-82 $\left.\mathrm{cm}\right)$ and from the monolith taken for microfossil analysis $(98-101 \mathrm{~cm}$ : thin peat layer; $107-110 \mathrm{~cm}$ : peaty topsoil of undisturbed podzol).

had been deeply worked (deep Ap horizon) prior to the planting of the beech trees, which are about 150 years old. The latter is fully in line with observations by Den Haan \& Sevink (2014), who found that throughout the estate the soil had been worked to a depth of $80-90 \mathrm{~cm}$.

Most remarkable is the chaotically stratified peat/white-sand complex, composed of a highly irregular three-dimensional 'mosaic' of mostly angular blocks of stacked white sand and peaty layers. Individual blocks vary in size from a few centimetres to several decimetres and lack a preferred orientation, but the southern face of the pit showed a rather horizontal stratification. A monolith used for screening microfossils was taken from this face. It exhibited a less chaotic stratification and a distinct peat layer, sampled for ${ }^{14} \mathrm{C}$ dating $(98-102 \mathrm{~cm})$.

Plant remains from the $0 / \mathrm{H}$ horizon of the underlying podzol (charred and non-charred plant remains of ericaceous species) were radiocarbon-dated to the early 3rd millennium BC and from the peat layer from the southern face (monolith) at around 2000 BC (samples GrA-64745 and GrA-64746 respectively; see Table 1). The more or less horizontally bedded sands above contained very few non-carbonised plant remains other than roots, and the radiocarbon-dated sample therefore concerns carbonised plant remains, which date from the onset of the 1st century BC (74-82 cm; GrA-64809).

\section{Pollen, other microfossils and radiocarbon dating}

The microfossil diagram 'Monnikenven- 1 ' is presented in Figure 5. Taxa starting with Alnus up to Spergula arvensis were included in the pollen sum. The exaggeration factor of the pollen curves is $10 \times$. Three zones can be distinguished. Zone A (the lower six samples) is characterised by an initially low concentration of pollen (high values of added Lycopodium spores) and local taxa such as Lycopodiella inundata, Littorella uniflora, Hydrocotyle vulgaris and filamentous algae (Zygnemataceae) that sporulate in springtime in shallow stagnant water. Fungal spore types, known as 'Type HdV-123' and 'Type HdV-12', point to mesotrophic conditions. In summary, zone A reflects an initial, amphibic local vegetation of a moorland pool (comparable to Gijzenveen; Van Geel et al., 2016). Some of the upper samples of zone A contain pollen of cerealia, but the frequencies of human impact indicators are low. The radiocarbon age and the low percentages of Fagus and cerealia point to a Subboreal age. There are no signs of disturbance or chronological problems in zone A.

The change in the pollen spectra from zone $\mathrm{A}$ to zone $\mathrm{B}$ is abrupt: suddenly various Late Holocene human impact indicators (crop plants and herbaceous taxa) appear: Secale and Cannabis show high percentages, and Fagopyrum and Centaurea cyanus occur regularly. In the Netherlands, the latter species arrived relatively late (Pals \& Van Geel, 1976; Bakels, 2012: High to Late Middle Ages). Fagopyrum was introduced as a relatively common crop during the Late Middle Ages and is continuously present in pollen records from relevant sedimentary sequences since then (De Klerk et al., 2015). Moreover, it was not found in the earlier (pre-Late Middle Ages) sediments from the Uddelmeer, which is the nearest lake in a dry sand landscape (Engels et al., 2016). The radiocarbon ages of samples GrA-59785 and GrA-58003 (reversed and both in the early first millennium $\mathrm{AD}$; Table 1) are thus in serious conflict with the known first and persistent presence of the above-mentioned two species in 
the Netherlands, if we assume that the sandy peat deposit of zone B is in situ. Such an assumption would evidently be incorrect and, alternatively, we conclude that this predominantly peaty sediment was formed in the early 1st millennium $\mathrm{AD}$ and was reworked in late medieval or later times, with concurrent admixture of relatively modern pollen. It should be emphasised that in zone B raised bog fungi (e.g. Anthostomella fuegiana, HdV-10 (a Calluna indicator), Tilletia sphagni) and Sphagnum spores are present, as well as charred Sphagnum leaves, indicating that the reworked material mainly consists of ombrotrophic Sphagnum peat (Van Geel, 1978). Such peat can be expected to grow during later stages in the development of mires (e.g. Van Geel et al., 2016). Zone C (humic sand) shows low pollen concentrations (high percentages of added Lycopodium spores), and most raised bog taxa are absent.

For the samples taken at Monnikenven-2, no extensive palynological record was made. Knowing the chronological and stratigraphical complications of Monnikenberg-1, attention was focused on the occurrence of pollen types of the relatively recently introduced species mentioned above. Secale and Fagopyrum were found in the peaty upper part of the podzol and in all overlying peat layers that were screened, while Cannabis and Centaurea cyanus were also observed. The situation - a conflict between relatively early radiocarbon ages (c. 2900-3000 cal BC; see Table 1) and late medieval or later pollen composition - is identical to that in Monnikenven-1 and here too it must be attributed to reworking of old peat. However, this does not hold for the peaty topsoil of the podzol, which lacks any sign of disturbance or reworking and most probably represents the 'in situ' land surface prior to the deposition of the 'chaotic peat/whitesand complex'.

\section{Age and origin of the mire fill}

The current fill of the mire comprises two units: (1) the 'early fill', consisting of both in situ fill and disturbed fill, and (2) the younger man-made 'estate fill' comprising soil material (podzol) used to level and raise the irregular surface of the 'natural' fill. The age of the 'early fill' can be constrained between about $3000 \mathrm{BC}$ (Monnikenven-2) and the time at which the disturbance took place. The 'estate fill' dates from around 1840 or slightly thereafter, as can be deduced from the 1837 map of the area on which a relatively large lake is indicated as well as the original parcels, which all disappeared upon the building of the estate (Van Aggelen, 1990).

For the nearby Laarder Wasmeren area around $3000 \mathrm{BC}$ a temporary high groundwater level was found (at about $230 \mathrm{~cm}+$ NAP), leading to marshy conditions and even some open water. This implies that the lower parts of the mire in the nearby Monnikenberg estate - mostly between $200 \mathrm{~cm}$ and $250 \mathrm{~cm}+\mathrm{NAP}$, with some deeper parts to about $170 \mathrm{~cm}+\mathrm{NAP}$ - were also very poorly drained at that time and will even have had some open water. Hydromorphic spodic B horizons easily acquire stagna- tive properties, and a sequential development of a mesotrophic, groundwater-fed moorland pool into an ombrotrophic rainwaterfed bog, and ultimately into a raised bog, has been extensively described (see e.g. Van Geel et al., 2016). Such a sequence most probably also took place here, as strongly suggested by the microfossil composition of the fill that contained taxa from an ombrotrophic bog.

As to the cause of the disturbance of the fill, the obvious explanation is the extraction of peat by removal of sandy topsoil material (blown in sand), and subsequent extraction of underlying peat for fuel. Small-scale peat extraction is known from many other parts of the Netherlands (see e.g. Borger, 1992; Neefjes et al., 2011; Verhoeven, 2013; Kieskamp et al., 2015; Van Beek et al. 2015), where specially raised bog peat with Sphagnum as the dominant component (the best peat quality for fuel) was extracted from small pits. The extraction created a highly irregular relief, very similar to that of the top of the peaty fill that we observed (Fig. 3d). In the Monnikenberg area, this must have taken place between the Late Middle Ages (after the widespread introduction of Fagopyrum and Centauria cyanus) and the 17th18th centuries, from which time on maps and historical records become available and are more precise. Peat extraction, if of later age, would have shown up in the historical records for that later period.

From the study of the Laarder Wasmeren area (Sevink et al., 2013), as well as from the in situ fill of the Monnikenberg mire, it is clear that from the Mid Holocene on sand was blown into the mires, particularly in the SW border zone, in line with the dominant wind direction for aeolian transport (see e.g. Koster, 2010). At a regional level, dimensions of this aeolian transport increased significantly in late medieval times, resulting in extensive drift-sand areas with a pronounced dune relief, known from the area to the south (Lage Vuursche) and characteristic for the Pleistocene sand areas of the central Netherlands (Koster, 2010). The presence of an extensive and thick peat/white-sand complex to the SW of the mire, which pre-dates the estate phase and rests on the peat/white-sand complex (see den Haan and Sevink 2014), is fully in line with the general pattern. It is furthermore clear that, at the time of peat extraction, sand drifting became a prominent phenomenon, given the dating of the onset of the youngest and major drift-sand phase in the Laarder Wasmeren area at about AD 1400 (Sevink et al., 2013).

Historical evidence for late medieval to early modern peat extraction is scant and circumstantial. Very little is known about the techniques used in the early extraction of peat from such small bogs in the Netherlands, and very few studies are available on these for NW Europe as a whole. These studies pertain to completely different types of environment (e.g. 'petgaten': Faber et al. 2016; a 'Hochmoor' in the Bayern Alps: Poschlod, 1990). However, based on our observations, a tentative description can be given. The aeolian sand supply must have caused the upper strata of the fill to be rather sandy and thus unsuited for peat extraction, and necessitated their 

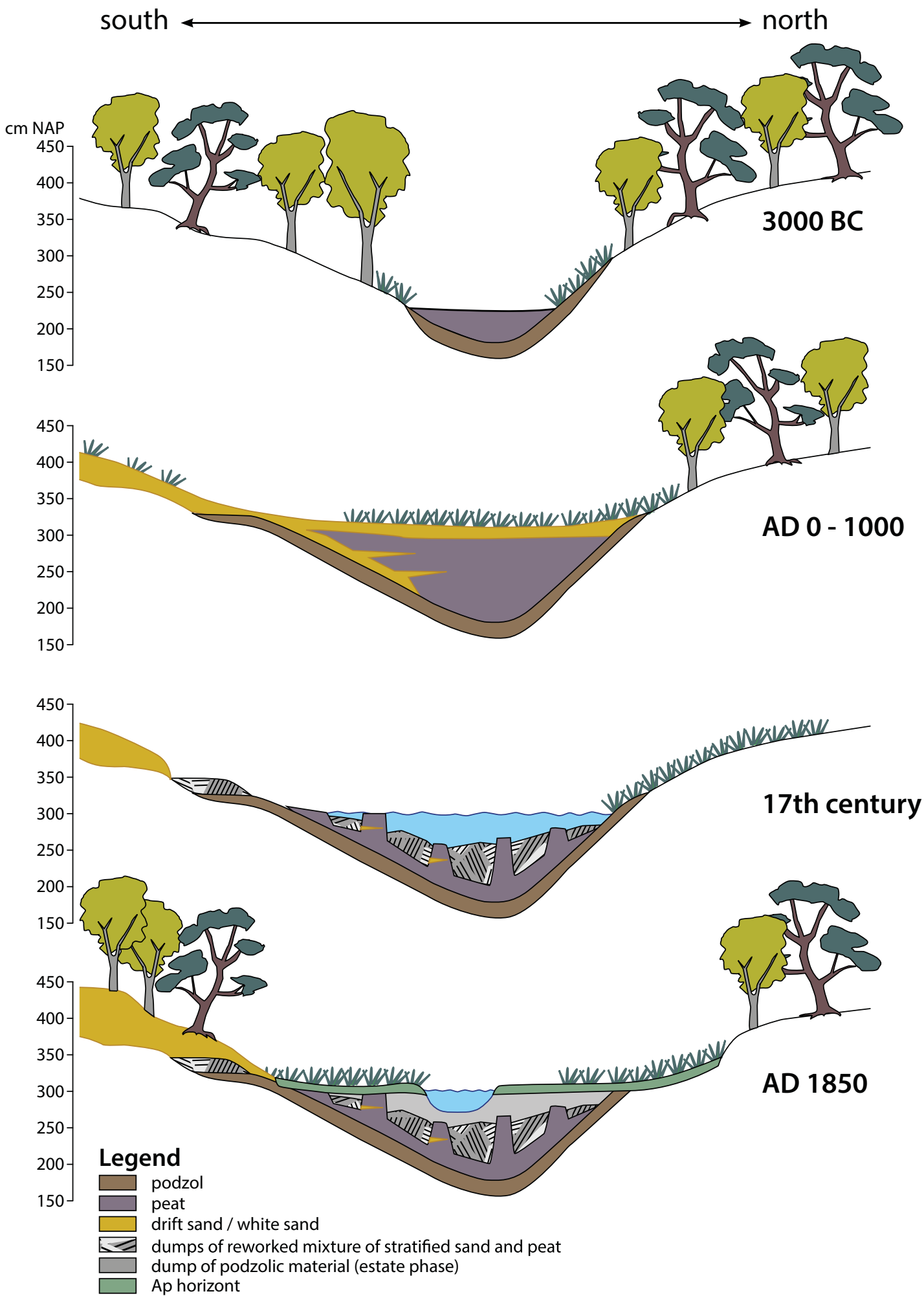

Fig. 6. Reconstruction of the phases in the history of the Monnikenberg estate.

removal to reach the more suitable (bog) peat. In the process, excavated material most probably was redeposited in extraction pits to form stratified white-sand and peat fills, composed of 'old sand and peat' contaminated with 'young' pollen. This explains the peat/white-sand complex in the border zone (M-
2), which apparently resulted from dumping of such stratified material, excavated in the more central part of the mire. The material must have been dug, rather than dredged, considering the well-preserved stratification of large lumps of sediment, which is unlikely to be retained if dredged. Furthermore, as is 
clear from the cross section (Fig. 3d), the altitude of the base of the peat/white-sand complex more or less equals the top of the mire fill (at $3.2 \mathrm{~m}+\mathrm{NAP}$ ), pointing to deposition of the excavated material in a non-aquatic border zone.

Van Aggelen (1990) provided a brief overview of the history of the area. In 1085, it became property of the Chapter of St Jan in Utrecht and, according to Van Aggelen, that may have been the start of peat extraction by the chapter's canons. J. Van der Laan (pers. comm., 2016) reports that, later on, chapters in Utrecht gave permits to local inhabitants to extract peat in the border zone between the Sticht (Utrecht) and Holland, including the peat area near Baarn and Lage Vuursche, but precise records of the location and timing of their activities seem not to exist. Van Aggelen mentioned the Veeneind ('veen' means peat; 'eind' means end), a road or path that ran from Hilversum to these small peat areas between Lage Vuursche and Hilversum, and stated that peat extraction resulted in small lakes that may well have included the Monnikenven. According to De Lange (1974), this road would date back to the early 16th century and its name would point to local peat extraction. In summary, this scant historical evidence provides some support for a late medieval to early modern age of the peat extraction.

The sequence of events is summarised in Figure 6, which evidences the complex history of the area. As to the earlier parts, they strongly resemble the sequence of phases observed in the Gijzenveen (Van Geel et al., 2016) and in the Laarder Wasmeren area (Sevink et al., 2013). The stagnant podzol was already fully developed by c. 3000 cal BC and ericaceous vegetation did occur nearby, while no indication was found for contemporaneous early farming. Though only a small part of the original fill is preserved - to about $170 \mathrm{~cm}$ in Monnikenven-1 and in the top of the podzol at Monnikenven-2 (and below) - the results for this undisturbed part do not support the theory that heathlands are linked to soil and vegetation degradation caused by early farming, as recently strongly advocated by Groenman-Van Waateringe \& Spek (2015/2016) and described by Jongmans et al. (2013). Our results are in line with those for the nearby Laarder Wasmeren area (Sevink et al., 2013), the recent study of the Gijzenveen (Van Geel et al., 2016) and the studies by Doorenbosch (2013) and Doorenbosch \& Van Mourik (2016), which all point to a more complex origin of heathland and its local early development by other causes than anthropogenic deforestation and agriculture.

\section{Conclusions}

The current lakes in the coversand area between Hilversum, Lage Vuursche and Baarn (Monnikenven and Groot Wasmeer) originated in at least the early 3rd millennium BC. The wetlands developed by stagnation on a dense hydromorphic podzol in depressions. At that time, these depressions were poorly drained and may even have had open water, because of the con- temporary high groundwater level. Over time, the depression in the Monnikenberg area, with initially a rather mesotrophic mire vegetation, became largely filled with ombrotrophic peat and intercalated drift sand, blown into the mire, while in the southern border zone drift sand later on covered the peaty fill. The early occurrence of drift sand is fully in line with results for the nearby Laarder Wasmeren area (Sevink et al., 2013), where drift sands from the same period abound. Our results also point to a local, very early development of heathland, i.e. prior to the introduction of Neolithic farming in this part of the Netherlands.

During the Late Middle Ages to Early Modern Times (between the 15th and 17th centuries) peat was extracted in the Monnikenberg area, most likely by digging and associated removal of sandy topsoil materials and intercalated sandy layers that were unsuited as fuel. The original mire fill was severely disturbed through a complex combination of topsoil removal, extraction of peat from small pits, redeposition of excavated topsoil material in these pits, and dumping of later excavated pit-fill in the border zone. We conclude that deposits in the southern border zone of the mire with a very unusual sedimentary structure for which no equivalent could be found in existing literature represent such dumps, later covered by drift sand. Similar structures, earlier found in the Groot Wasmeer, suggest that there too peat was extracted after removal of overlying sand.

The anthropogenic origin of the dumps in the Monnikenven area could only be established by combining radiocarbon dating and pollen analysis. It was this combination that allowed us to conclude that truly 'old' materials were reworked during a far more recent period (15th-17th centuries AD), a conclusion which hinged very much upon the presence of pollen from imported species (Fagopyrum, Centaurea cyanus) of which the time of introduction is well known. The same practice, viz. local extraction of ombrotrophic peat from bogs covered by drift sand, was common elsewhere in the Pleistocene coversand areas of the Netherlands (see e.g. Kieskamp et al., 2015). Therefore, dumps of excavated sandy material with similar sedimentary structure are likely to be far more widespread.

The current landscape is entirely man-made and the result of large-scale landscape modification in the mid-19th century, when the Monnikenberg estate was constructed and the parcel with the former mire, with a presumably very irregular surface, was filled in by sandy podzol material, excavated in the former higher parts of the parcel, and completely levelled.

\section{Acknowledgements}

Many thanks are due to the Goois Natuurreservaat (GNR) and, in particular, Poul Hulzink for permission to dig a large pit in the Monnikenberg mire and indeed for digging that pit for us. Its interest, as a nature conservation organisation, in the origin and geological history of its terrains is exemplary and we sincerely thank GNR for its support. Peter Vos and Ward Koster were 
equally puzzled by the strange sedimentary structures in the pit and aided us in the interpretation of their genesis. Michael den Haan, who participated in the earlier survey of the area, helped us with the figures illustrating the characteristics of the mire and its fill. Stefan Engels produced the pollen diagram from the pollen counts produced by the second author, and Jan van Arkel took care of the layout of the illustrations.

\section{Supplementary material}

To view supplementary material for this article, please visit https://doi.org/10.1017/njg.2017.9

\section{References}

Bakels, C., 2012. The early history of Cornflower (Centaurea cyanus L.) in the Netherlands. Acta Palaeobotanica 52(1): 25-31.

Beug, H.J., 2004. Leitfaden der Pollenbestimmung für Mitteleuropa und angrenzende Gebiete. Pfeil (Munich): 542 pp.

Borger, G.J., 1992. Draining - digging - dredging; the creation of a new landscape in the peat areas of the Low Countries. In: Verhoeven, J.T.A. (ed.): Fens and bogs in the Netherlands: vegetation, history, nutrient dynamics and conservation. Geobotany 18: 131-171.

Bronk Ramsey, C., 2013. 0xCal 4.2 Web Interface Build (78).

De Klerk, P., Couwenberg, J. \& Joosten, H., 2015. Pollen and macrofossils attributable to Fagopyrum in western Eurasia prior to the late Medieval: an intercontinental mystery. Palaeogeography, Palaeoclimatology, Palaeoecology 440: 1-21.

De Lange, P.W., 1974. Hilversums oude kerktoren weer in ere hersteld, Tussen Vecht en Eem 4(2): 47-50.

Den Haan, M. \& Sevink, J., 2014. Bodemonderzoek ten behoeve van ecologisch herstel en inrichting van verbindingszone in het gebied Monnikenberg. Rapport in opdracht van GNR (Hilversum): $73 \mathrm{pp}$.

Doorenbosch, M., 2013. Ancestral heaths. Reconstructing the barrow landscape in the central and southern Netherlands. PhD Thesis. University of Leiden (Leiden): $280 \mathrm{pp}$.

Doorenbosch, M. \& Van Mourik, J.M., 2016. The impact of ancestral heath management on soils and landscapes: a reconstruction based on paleoecological analyses of soil records in the central and southeastern Netherlands. SOIL 2, 311-324.

Engels, S., Bakker, M.A.J., Bohncke, S.J.P., Cerli, C., Hoek, W.Z., Jansen, B., Peters, T., Renssen, H., Sachse, D., van Aken, J.M., van den Bos, V., van Geel, B., van Oostrom, R., Winkels, T. \& Wolma, M., 2016. Centennial-scale lake-level lowstand at Lake Uddelermeer (The Netherlands) indicates changes in moisture source region prior to the 2.8-kyr event. The Holocene, 26(7), 1075-1091.

Faber, A.H., Kooijman, A.M., Brinkkemper, O., Van der Plicht, J. \& Van Geel, B., 2016. Palaeoecological reconstructions of vegetation successions in two contrasting former turbaries in the Netherlands and implications for conservation. Review of Palaeobotany and Palynology 233: 77-92.

Fægri, K., Iversen, J., Kaland, P.E. \& Krzywinski, K. (eds). 1989. Textbook of pollen analysis. John Wiley and Sons (Chichester, UK): 328 pp.
Groenman-Van Waateringe, W. \& Spek, T. 2015/2016. Heatland and the palynology of prehistoric barrows. Reflections on the interrelations between soil formation and pollen infiltration. (Palaeohistoria 57/58.) University of Groningen \& Barkhuis (Groningen).

Jongmans, A.G., Van den Berg, M.W., Sonneveld, M.P.W., Peek, G.J.W.C. \& Van den Berg van Saparoea, R.M., 2013. Landschappen van Nederland. Wageningen Academic Publishers (Wageningen): 942 pp.

Kieskamp, A.A.M., Jansen, A.J.M., Sevink, J. \& Eysink, A.T.W., 2015. Hydroecologische systeemanalyse Beerzerveld - De noodzaak van interne en externe maatregelen. Coöperatie Unie van Bosgroepen (Ede): 80 pp.

Koster, E.A., 2010. Origin and development of Late Holocene drift sands: geomorphology and sediment attributes. In: Fanta J. \& Siepel H. (eds): Inland drift sand landscapes. KNNV Publishing (Zeist): 25-48.

Mook, W.G. \& Van der Plicht, J., 1999. Reporting ${ }^{14} \mathrm{C}$ activities and concentrations. Radiocarbon 41: 227-239.

Moore, P.D., Webb, J.A. \& Collinson, M.E., 1991. Pollen analysis. Blackwell Science (Malden, MA): $217 \mathrm{pp}$.

Neefjes, J., Brinkkemper, 0., Jehee, J. \& Van de Griendt, W., 2011. Cultuurhistorische atlas van de Vecht: biografie van Nederlands grootste kleine rivier. WBooks (Zwolle): $336 \mathrm{pp}$.

Pals, J.P. \& Van Geel, B., 1976. Rye cultivation and the presence of cornflower (Centaurea cyanus L.). Berichten van de Rijksdienst Oudheidkundig Bodemonderzoek 26: 199-204.

Poschlod, P., 1990. Vegetationsentwicklung in abgetorften Hochmooren des bayerischen Alpenvorlandes unter besonderer Berücksichtigung standortkundlicher und populationsbiologischer Faktoren. Dissertationes Botanicae 152: $331 \mathrm{pp}$.

Reimer, P. J., Bard, E., Bayliss, A., Beck, J. W., Blackwell, P. G., Ramsey, C. B., Buck, C.E., Cheng, H., Edwards, R.L., Friedrich, M., Grootes, P.M., Guilderson, T.P., Haflidason, H., Hajdas, I., Hatté, C., Heaton, T.J., Hoffmann, D.L. Hogg, A.G., Hughen, K.A., Kaiser, K.F., Kromer, B., Manning, S.W., Niu, M., Reimer, R.W., Richards, D.A., Scott, E.M., Southon, J.R., Staff, R.A., Turney, C.S.M. \& Van der Plicht, J., 2013. IntCal13 and Marine13 radiocarbon age calibration curves $0-50,000$ years cal BP. Radiocarbon 55(4), 1869-1887.

Sevink, J. \& Den Haan, M., 2012. Het natuurgebied Monnikenberg: bodem, hydrologie en potentiële effecten van het 'Plan Monnikenberg'. Rapport Sevink Consultancy (Hilversum): $31 \mathrm{pp}$.

Sevink, J., Koster, E.A., Van Geel, B. \& Wallinga, J., 2013. Drift sands, lakes and soils: the multiphase Holocene history of the Laarder Wasmeren area near Hilversum, The Netherlands. Netherlands Journal of Geosciences / Geologie en Mijnbouw 92, 243-266.

Sevink, J., Siebelink, B., Strijbis, P. \& De Haan, F., 2012. Nieuwe schoonheid: De sanering van de Laarder Wasmeren. Waterschap Amstel, Gooi en Vecht/Provincie Noord-Holland/Goois Natuurreservaat (Hilversum): $46 \mathrm{pp}$.

Sevink, J., Vlaming, M.C., Van den Berg, W.J., Khodabux, E.R., Landsmeer, D. \& Stoeten, G.J., 2008. De sanering van het Laarder Wasmerengebied. Bodem 5: 8-11.

Van Aggelen, K., 1990. Huis met historie: De Monnikenberg. Geschiedenis van het klooster De Stad Gods. Eigen Perk 3: 80-84

Van Beek, R., Maas, G. J., \& Van den Berg, E., 2015. Home turf: an interdisciplinary exploration of the long-term development, use and reclamation of raised bogs in the Netherlands. Landscape History 36(2): 5-34. 
Van Geel, B., 1978. A palaeoecological study of Holocene peat bog sections in Germany and the Netherlands, based on the analysis of pollen, spores and macro-and microscopic remains of fungi, algae, cormophytes and animals. Review of Palaeobotany and Palynology 1(31): 1-120.

Van Geel, B. \& Aptroot, A., 2006. Fossil ascomycetes in Quaternary deposits. Nova Hedwigia 82: 313-329.
Van Geel, B., Brinkkemper, O., Weeda, E.J. \& Sevink, J., 2016. Formation, vegetation succession and acidification of a mid-Holocene moorland pool in the western Netherlands. Netherlands Journal of Geosciences / Geologie en Mijnbouw 96(1): 17-27.

Verhoeven, J.T. (ed.), 2013. Fens and bogs in the Netherlands: vegetation, history, nutrient dynamics and conservation. (Geobotany vol. 18.) Springer Science \& Business Media (New York): 491 pp. 